\title{
The acetic acid test in evaluation of subclinical genital papillomavirus infection: A comparative study on penoscopy, histopathology, virology and scanning electron microscopy findings
}

A Wikström, M-A Hedblad, B Johansson, M Kalantari, S Syrjänen, M Lindberg, $G$ von Krogh

\begin{abstract}
Objectives-To evaluate colposcopic criteria in acetowhite lesions of the penis ("penoscopy") for the diagnosis of subclinical genitoanal papillomavirus infection (GPVI) compared with histopathological criteria of HPV involvement and to various hybridisation assays for HPV DNA detection, and to depict typical lesions by scanning electron microscopy.

Design-The study included 101 randomly selected male partners of females with known GPVI, or with penile symptoms such as itching, burning and dyspareunia who did not exhibit overt genital warts but appeared to be afflicted with acetowhite penile lesions after topical application of $5 \%$ acqueous acetic acid. Lesions were judged by penoscopy as either typical, conspicuous or nontypical for underlying HPV infection. Biopsy specimens from 91 men were examined by light microscopy and by either Southern blot (SB), polymerase chain reaction (PCR) and/or in situ hybridisation (ISH) assays for the presence of HPV DNA of the HPV types $6,11,16,18,31,33$ and 42 (Group A). From another ten men lesions clinically typical for GPVI were also examined topographically by scanning electronic microscopy (Group B).
\end{abstract}

Setting-The STD out-patient clinic of the Department of Dermatovenereology of Karolinska Hospital, Stockholm, Sweden.

Results-Group $A$ Seventy eight (86\%) of the biopsied lesions met the penoscopy criteria of being either typical of or conspicuous for GVPI. The agreement between penoscopy and histopathology was fairly good, as HPV diagnosis was made by both methods in $56(62 \%)$ of the cases. The reliability of applying strict colposcopic hallmarks was further substantiated by the finding that $55(60 \%)$ of the biopsy specimens taken from penoscopically typical/conspicuous lesions contained HPV DNA. However, there are diagnostic pitfalls for the acetic acid test. Coexistence of an eczematoid reaction with changes indicative of HPV influence was detected in six (7\%) of the cases, while an inflammatory response only occurred in $17(19 \%)$ of the specimens. Additional histopathological diagnoses (normal epithelium, lichen sclerosus et atrophicus, balanitis circinata parakeratotica, verruca plana) were established in another eight $(9 \%)$ of the cases. Among the HPV DNA positive cases, all of the HPV types tested for were detected with the exception of HPV 18. A severe penile intraepithelial neoplasia (PIN III) was revealed in five ( $5 \%$ ) of biopsies; HPV 16 was present in two and HPV 42 in one of these biopsy specimens.

Group B-Scanning electron microscopy depiction harmonised with the penoscopy findings showing that subclinical GPVI characteristically exhibits a well demarcated, slightly elevated border and that the central area of lesions often displays a "groove" in which the epithelium appears to be thin with protrusions from beneath that probably represent capillaries.

Conclusion-Use of the acetic acid test for evaluation of GPVI should be combined with a colposcopic evaluation based on strict topographic hallmarks, followed by a directed biopsy for light microscopic evaluation. We found that the positive predictive value of colposcopy was as high when correlated with histopathological findings $(\mathbf{7 2} \%)$ as when virological methods were used, whether HPV DNA hybridisation testing was performed with the well established SB and ISH assays ( $45 \%)$, or by applying the newly introduced and highly sensitive PCR assay as well (71\%). False positivity from the acetic acid test occurs and is mainly due to inflammatory conditions but also to the presence of other conditions. Epithelial fissures are evidently associated with some subclinical GPVI lesions and may potentially represent loci minores for infectious stimuli and perhaps facilitate the transmission of some blood-borne STDs. We propose that the term "papillomavirus balanoposthitis" should be used for penile HPV infection associated with inflammatory responses. Our study indicates that PIN 
III frequently occurs in a subclinical form and may be associated with not only previously identified "high-risk" HPV types such as type 16, but also with the HPV type 42 that has not previously been considered as oncogenic.

\section{Introduction}

Human papillomaviruses (HPV) are a heterogenous group of viruses. So far, almost 70 different genotypes have been discovered. Some HPV types exhibit a preferential tropism for mucous membranes, while others rather have predilection for fully keratinized dry skin. The former viruses are harboured mostly in the genitoanal area, but are found in the ororespiratory mucosa and in the esophageal epithelium as well..$^{1-3}$

In recent years the use of various hybridisation assays for HPV DNA detection has demonstrated that the predominant majority of individuals with biologically active genitoanal papillomavirus infection (GPVI) is afflicted merely with subclinical flat epithelial lesions that remain invisible to naked eye examination for a considerable time. Evidently the visible genitoanal warts that by tradition have been denominated condylomas (condylomata acuminata) only represent the "tip of the ice-berg".

Some GPVI lesions tend to persist for a considerable time and to be associated with various degrees of dysplastic transformation (intraepithelial neoplasia), in particular of the uterine cervix (cervical intraepithelial neoplasia; CIN), where about $15 \%$ of cases progress to carcinoma in situ in time. ${ }^{4-6}$ The latter type of biological behaviour is associated with "high-risk" HPV types such as HPV 16 and $18,{ }^{7-11}$ as opposed to "low-risk" HPV such as types 6 and 11, which are almost invariably associated with benign epithelial proliferation. ${ }^{1213}$

In females it has been shown that flat lesions sometimes are symptomatic, sensations such as itching, burning and/or dyspareunia originating from associated epithelial fissures. ${ }^{1416}$

Although it is of great clinical relevance to recognise correctly the presence of such lesions, no consistently reliable diagnostic methods for routine use have yet been presented for their identification. Some investigators claim that the epithelial whitening that will usually occur from topical application of an aqueous solution of 3-5\% acetic acid represents a reasonably accurate method, in particular when combined with magnification by colposcopic equipment..$^{17-26}$ Nevertheless, no unequivocally uniform colposcopic criteria have been presented for HPV associated acetowhite lesions. The most consistent pattern appears to be the presence of a well demarcated, slightly elevated acetowhitened epithelium in which a punctuated capillary pattern often can be distinguished.

Histologically, the following morphologic patterns are considered as characteristic of biologically active HPV infection: the presence of an epidermal hyperplasia with acanthotic elongation of the rete ridges, hyper- and parakeratosis, and koilocytosis, associated with the existence of dilated vessels of the corium papillae and some degree of a subepidermal mononuclear inflammatory component. Furthermore, a moderate to severe intraepithelial neoplasia may be seen when lesions are associated with any of the "highrisk" HPV types. Only the presence of koilocytes is pathognomonic of the influence of HPV on the epithelium; ${ }^{1727-33}$ this hallmark is in general associated with the occurrence of relatively high virus quantities. ${ }^{34}$ Acetowhite lesions are more frequently void of koilocytosis than is the case for classical condylomas. ${ }^{35}$

This study focuses on the sensitivity, specificity and predictive value of the colposcopic findings in flat acetowhite lesions of the penis ("penoscopy") as compared with histological criteria of HPV infection and to HPV DNA hybridisation in biopsy tissue. The hybridisation assays performed include the well established Southern blot (SB) and in situ hybridisation (ISH) techniques and also the newly introduced and extremely sensitive polymerase chain reaction (PCR) which may detect as few as $10-100 \mathrm{HPV}$ DNA copies. ${ }^{36} \mathrm{~A}$ description of scanning electron microscopic findings in penoscopically typical lesions is also given.

\section{Methods \\ Patients}

One hundred and one randomly selected heterosexual uncircumcised males who attended an STD out-patient clinic because of either penile symptoms such as itching, burning and dyspareunia, or as partners of females with known GPVI without any clinical HPV lesions participated in the study. Aqueous 5\% acetic acid was applied to penile epithelium for five minutes by having patients to hold a wettened gauze against the entire penile epithelium, keeping the foreskin retracted.

\section{Penoscopy}

Acetowhite lesions were evaluated at magnification $(8-20 \times 12,5)$ using a Zeiss photocolposcope ("penoscopy") and lesions were classified according to the following grading: (1) Typical, (fig 1) that is, the presence of well demarcated lesions with a slightly elevated border and the occurrence centrally of punctuated capillaries with or without an associated epithelial depression ("groove"); (2) Conspicuous, (fig 2) that is, the presence of well demarcated slightly elevated lesions lacking discernible punctuated capillaries; and 3) Non-typical, (fig 3) that is, the presence of lesions exhibiting a ragged border and lacking punctuated capillaries.

\section{Biopsies}

Biopsy specimens were obtained subsequent to applying local infiltration anaesthesia using lidocain- $\mathrm{HCl} 5 \mathrm{mg} / \mathrm{ml}$ (Astra, Sweden).

\section{Group $A$}

A specimen about $4-6 \mathrm{~mm}$ in diameter was obtained from 91 patients with various peno- 


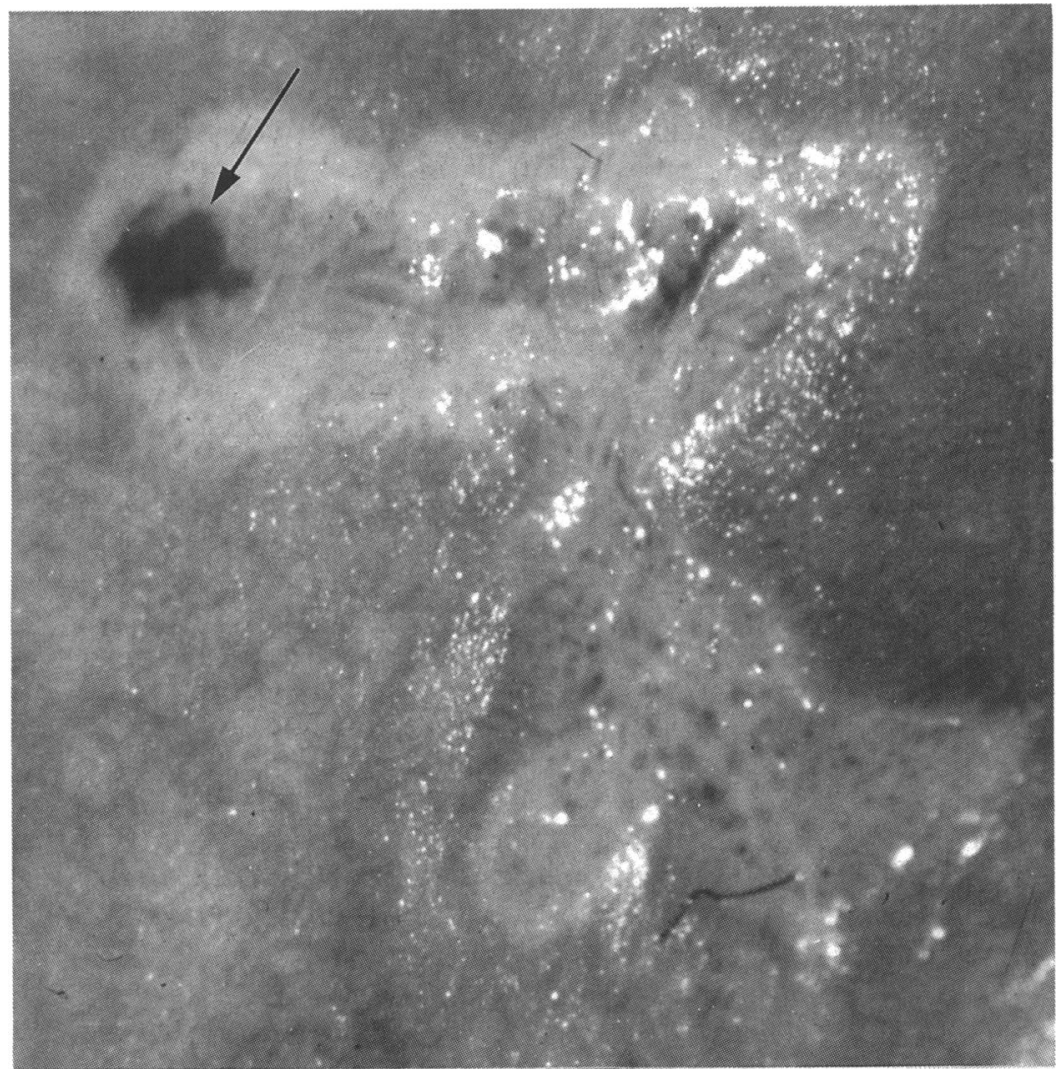

Figure 1 Well demarcated acetowhite lesion on the foreskin. The border is slightly elevated while a central depression ("grove") appears in part of the lesion (top) where a slight haemorrhage is noted (arrow). A punctuate capillary pattern is clearly discernable, in particular in the bottom part of the lesion. $(\times 20 \times 12.5$ (Zeiss photocolposcope $))$.

Figure 2 Well demarcated, slightly elevated acetowhite lesions on the glans penis. The surface is smooth. No punctuated capillaries are seen.

$(\times 12 \times 12.5$ (Zeiss photocolposcope)). neutral $10 \%$ formalin and paraffin embedded for routine histology and ISH, while the other half was frozen at $-70^{\circ} \mathrm{C}$ for SB and PCR.

\section{Group B}

From ten men exhibiting lesions classified as penoscopically typical, a single biopsy was performed that entailed the entire acetowhite area and a 1-2 mm wide zone of adjacent epithelium. The specimen was subsequently attached to a piece of cork using pin-point needles, followed by fixation for scanning electron microscopy.

Histology classification

The histological analysis, consistently performed by one of the investigators $(\mathrm{MH})$ without knowledge of either the penoscopy findings or the DNA hybridisation results, was classified according to the following criteria: (1) Typical: the presence of epidermal hyperplasia, acanthosis, hyper- and parakeratosis and koilocytosis; (2) Conspicuous: all of the criteria above except for koilocytosis; (3) Conspicuous + eczematoid reaction: the criteria as in (2) as well as the presence of an eczematous inflammatory response involving the epidermis. (4) Eczematoid reaction only; and (5) Other conditions. Any intraepithelial neoplasia (PIN) was graded (PIN I-III) according to the criteria defined previously. ${ }^{1337} 38$

\section{Hybridisation assays}

Owing to relatively small biopsy specimens, all of the various hybridisation methods could not be performed on samples from all of the 91 patients. Tissue sufficient for SB analysis was obtained in 65 males, and PCR could be performed in 61 of the samples. ISH was carried out on 72 specimens. All three assays (SB, PCR, ISH) were carried out in only 27 biopsies but all 91 samples were analysed with at least one of the assays.

\section{Southern blot hybridisation (SB)}

(a) Preparation and restriction cleavage of

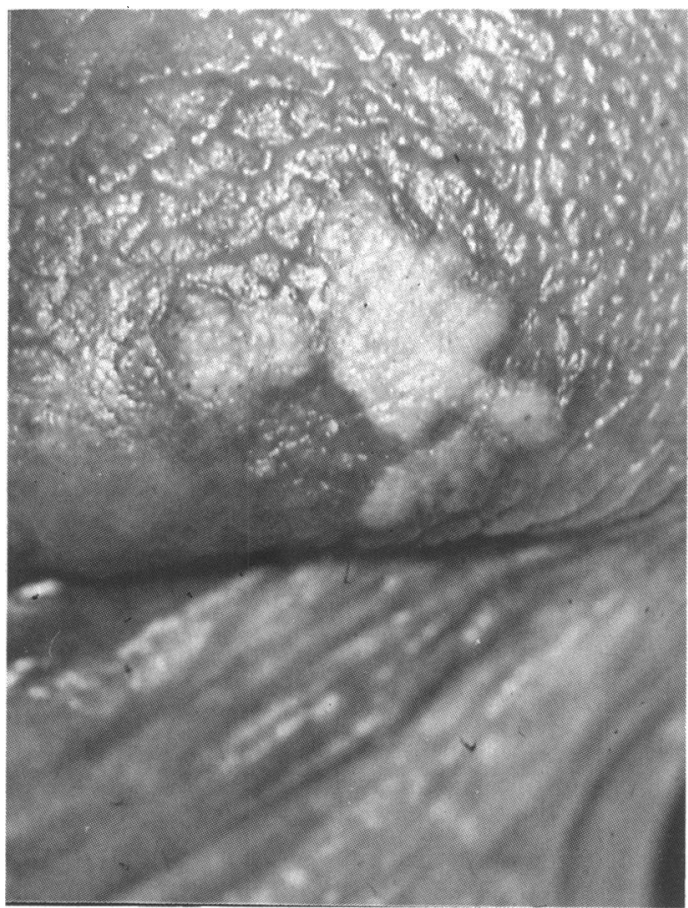

Figure 3 A confluent acetowhitening occurring on the glans penis, in the coronal sulcus and on the foreskin. Some lesions are well demarcated, in other areas the border is somewhat rugged (arrows). No punctuated capillaries are present. Some of the acetowhitening in this man occurred on slightly erythematous epithelium, indicating an inflammatory component. $(\times 8 \times 12.5$ (Zeiss photocolposcope $)$ )

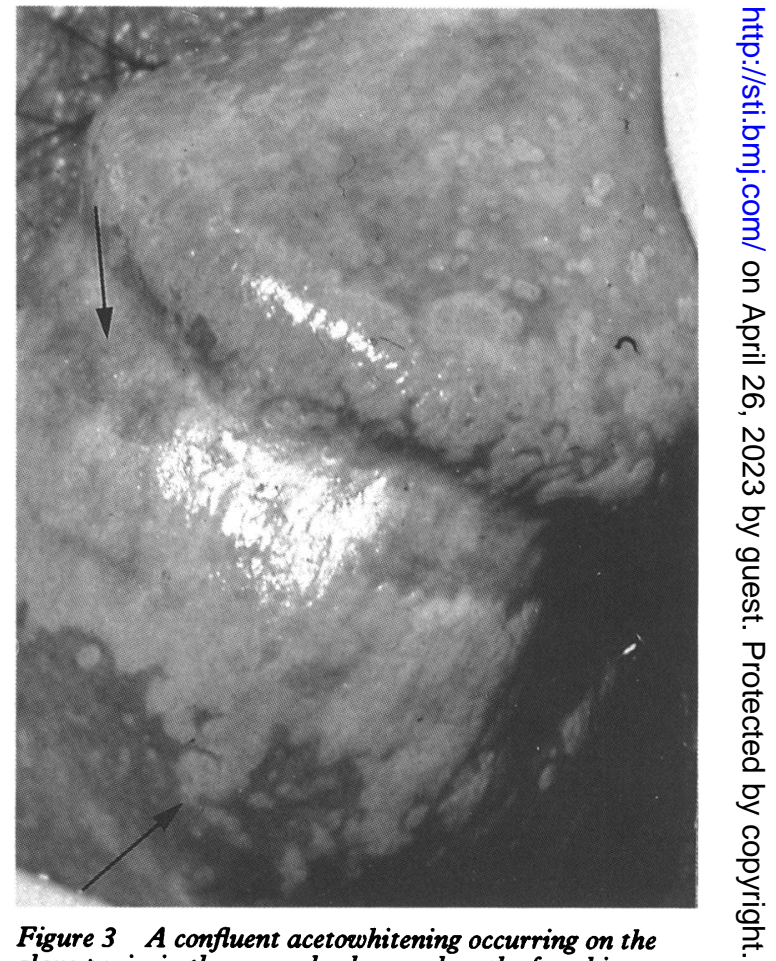


$D N A$ The thawed specimens were minced and dissolved at $37^{\circ} \mathrm{C}$ in lysis buffer containing $50 \mathrm{mM}$ Tris- $\mathrm{HCl}, \mathrm{pH} 7 \cdot 5,0.5 \%$ SDS, $10 \mathrm{mM}$ EDTA, $50 \mathrm{mM} \mathrm{NaCl}$ and $150 \mu \mathrm{g}$ Proteinase $\mathrm{K}$. After phenol extraction and ethanol precipitation the DNA was pelleted by centrifugation at top speed in an Eppendorf centrifuge for 15-30 min. The pellet was dried and dissolved in $100 \mu \mathrm{l}$ distilled water. This was further purified by using a GENECLEAN-kit (BIO 101, California, USA). Restriction enzyme digestion was performed by adding $10 \mu \mathrm{l} 10 \times \mathrm{M}$ buffer and $10 \mu \mathrm{l}$ PstI (Pharmacia LKB, Stockholm, Sweden; 13000 units) to $80 \mu \mathrm{l}$ DNA solution, and incubation at $37^{\circ} \mathrm{C}$ over night.

(b) Electrophoresis and blotting Electrophoresis and blotting were performed using a Probe Tech I machine (Oncor Inc., Maryland, USA). The digested samples were supplemented with $10 \mu$ l loading buffer (Oncor Inc.) and run according to the manufacturers instructions. The vacuumtransfer was performed for 90 min using Hybond $\mathrm{N}$ membranes (Amersham, Buckingshamshire, England). After transfer the membranes were illuminated on a UV light box for $5 \mathrm{~min}$.

(c) Hybridisation Cloned genomes of HPV 6 $11,16,18,31$ and 42 were used as probes in the hybridisation. HPV 6, 11, 16 and 18 were kindly provided by Prof $\mathrm{H}$ zur Hausen, Deutsches Krebsforschungszentrum, Heidelberg, Germany. HPV 31 was obtained from Dr A Lorincz, BRL, Maryland, USA and HPV 42 from Prof G Orth, Institute Pasteur, Paris, France. The complete genomes were cut out and removed from the vector before being labelled. Genome (25-30 ng) was labelled using the Multiprime kit of Amersham Inc. The reaction was performed according to the manufacturers instructions, using either ${ }^{32} \mathrm{P}$ labelled dATP or dCTP (Amersham; $3000 \mathrm{Ci}$ / $\mathrm{mmol}$ ) to a specific activity of at least $5 \times 10^{8}$ $\mathrm{dpm} / \mu \mathrm{g}$ DNA.

The Hybond membrane was prehybridised in a solution containing $20 \%$ deionized formamide $5 \times$ SSC, $50 \mathrm{mM}$ sodium phosphate, pH 6.8, $5 \times$ Denhardt's solution, $0.5 \%$ SDS and $250 \mu \mathrm{l} / \mathrm{ml}$ sheared and denatured herring sperm DNA (Boehringer, Mannheim, West Germany) at $42^{\circ} \mathrm{C}$ for $1-4 \mathrm{~h}$. Low-stringency hybridisation was performed at $42^{\circ} \mathrm{C}$ over night in a solution of the same composition as used for prehybridisation, except that the sodium phosphate was at $20 \mathrm{mM}$ and herring sperm DNA at $100 \mu \mathrm{g} / \mathrm{ml}$ concentration respectively. Washing was carried out in $2 \times$ SSC, $0.1 \%$ SDS, once at room temperature and three times at $52^{\circ} \mathrm{C}$. The filter was exposed to X-ray film (Hyperfilm $\beta$-MAX; Amersham Inc.) for one to seven days.

In situ hybridisation From formalin fixed and paraffin embedded specimens eight serial sections ( $5 \mu \mathrm{m}$ thick) were cut. In situ hybridisation was performed to detect HPV DNA types $6,11,16,18,31,33$ and 42 . One section was hybridised with the vector pBR 322 as a negative control. The HPV probes $6,11,16,18$ and 31, 33, 42 were kindly provided from Prof $\mathrm{H}$ zur Hausen (Deutsche Krebsforschungszen- trum, Heidelberg, Germany) and Prof G Orth (Pasteur Institute, Paris, France), respectively. The probes were biotinylated with nick translation according to the standard procedures; ISH was done as earlier described with biotin 11-UTP (Sigma). ${ }^{39}$ Shortly after deparaffinisation and deproteinisation (Proteinase $\mathrm{K}$, $0,5 \mathrm{mg} / \mathrm{ml} \mathrm{PBS}, 15 \mathrm{~min}$ at $37^{\circ}$ ) hybridisation solution was added onto the sections and denatured in an incubator by heat $\left(90^{\circ}, 10 \mathrm{~min}\right)$. The hybridisation solutions contained $50 \%$ formamide, $2 \times$ SSC, $10 \%$ dextran sulfate, $0,4 \mathrm{mg} / \mathrm{ml}$ herring sperm DNA and $1 \mu \mathrm{g} / \mathrm{ml}$ biotinylated HPV DNA prove. The hybridisation was carried out under high stringency conditions for 2 hours at $50^{\circ} \mathrm{C}$. Post-hybridisation washes $5 \mathrm{~min}$ each included $2 \times \mathrm{SSC} 0,1 \%$ SDS once at RT, $0,2 \times$ SSC, $0,1 \%$ SDS three times at $60^{\circ} \mathrm{C}$ and $2 \times \mathrm{SSC}$ once at room temperature. The detection of biotinylated hybrid was performed by sequential incubation in streptavidin, alkaline phosphate $(20 \mathrm{~min}$ at $37^{\circ} \mathrm{C}$ ) and substrate solution of BCIP (5bromo- 4-chloro 3-indolylphosphate) and NBT (nitroblue tetrazolium) for two hours at $37^{\circ} \mathrm{C}$. The reaction was stopped by three washes with water and mounted with aqua mount.

PCR PCR ${ }^{40}$ was performed as described previously ${ }^{41}$ using $5 \mu \mathrm{l}$ of the DNA prepared for Southern blotting. The primers used for HPV 6 were located in the E7 gene at position 563-582 and 698-718 of the genome. The primers used for HPV 16 were localised in the upstream regulatory region at positions 7763 7781 and $61-86$ of the genome. The concentration of each primer was $20 \mathrm{pmol}$ per $50 \mu \mathrm{l}$ reaction volume and the primer pairs for $H V P$ 6 and 16 were run together in the same reaction ("multiplex PCR"). The reactions were performed in an automated thermocycler programmed for 30 cycles of DNA denaturation $\left(95^{\circ} \mathrm{C}\right)$, primer annealing $\left(55^{\circ} \mathrm{C}\right)$, and template extension $\left(72^{\circ} \mathrm{C}\right)^{41}$

Analysis of the PCR product was carried out using 3\% NuSieve (FMC BioProducts, Maine, USA) agarose gels containing $0,5 \mu \mathrm{g} / \mathrm{ml}$ of ethidium bromide. As a size standard for the bands on the gel, $\Phi \mathrm{X} 174 \mathrm{DNA}$ restricted with Hae III was used (Pharmacia LKB Biotechnology, Stockholm, Sweden). A band at $156 \mathrm{bp}$ or at $227 \mathrm{bp}$ signified a sample positive for HPV 6 or 16 respectively. To avoid contamination, the PCR was performed in several separate work stations, the reagents were aliquoted from master mixes and the samples were added using piston-driven pipettes (Gilson, France). Solution controls without added DNA were included. High and low positive controls were cloned genomes at $10 \mathrm{pg}$ and $100 \mathrm{fg}$ respectively.

Scanning electron microscopy The biopsies were fixed in $2,5 \%$ glutaraldehyde in a $0,1 \mathrm{M}$ phosphate buffer, postfixed in $1 \%$ osmium tetroxide, rinsed in distilled water, dehydrated and critical point dried. The samples were mounted on aluminium stubs, sputtered with gold and viewed in a Philips 400 scanning electron microscope. 
Table 1 Correlation between penoscopy and histology findings (\%)

\begin{tabular}{llll}
\hline & \multicolumn{2}{l}{ Histopathology } & \\
\cline { 2 - 3 } Penoscopy & $\begin{array}{l}\text { HPV condordant } \\
\text { influence }\end{array}$ & Other conditions & Total \\
\hline Typical/conspicuous & $56(62)$ & $22(24)$ & $78(86)$ \\
Non-typical & $10(11)$ & $3(3)$ & $13(14)$ \\
Total & $66(73)$ & $25(27)$ & $91(100)$ \\
\hline
\end{tabular}

Table 2 HPV DNA hybridisation results (\%)

\begin{tabular}{llll}
\hline \multirow{4}{*}{ HPV type } & \multicolumn{3}{l}{ Number of positive samples } \\
\cline { 2 - 4 } & Southern blot $(n=65)$ & In situ $(n=72)$ & $P C R(n=61)$ \\
\hline 6 & 8 & 2 & 26 \\
11 & 2 & 0 & ND \\
16 & 6 & 2 & 6 \\
18 & 0 & 0 & ND \\
31 & 1 & 0 & ND \\
33 & $\mathrm{ND}$ & 1 & $\mathrm{ND}$ \\
42 & 7 & 7 & 12 \\
Unknown & 6 & $\mathrm{ND}$ & \\
Coexistence of more than one & 2 & 2 & $44(72)$ \\
HPV type & & $14(19)$ & \\
Total positive & $32(49)$ & & \\
\hline
\end{tabular}

\section{Results}

Group $A$

By penoscopy 91 lesions were assessed, of which 49 (54\%) were typical, 29 (32\%) conspicuous and $13(14 \%)$ non-typical

Sixty six $(73 \%)$ lesions were histologically consistent with GPVI. Of these, $44(48 \%)$ showed koilocytosis, $16(18 \%)$ a conspicuous hyperplasia only, and six (7\%) biopsies had an eczematoid component as well. An eczematoid reaction only was detected in $17(19 \%)$ of biopsies. Intraepithelial neoplasia was present in $18(20 \%)$ of lesions; PIN I was detected in three, PIN II in ten and PIN III in another five cases. In three cases the presence of other conditions was established: lichen sclerosus et atrophicus, verruca plana, balanitis circinata parakeratotica in one case each. An apparently normal epithelium was present in five cases.

The correlation between penoscopy and histology findings is shown in table 1. Typical/ conspicuous penoscopy findings corresponded to HPV concordant influence in $56(62 \%)$ of biopsies, while $22(24 \%)$ of penoscopically suspected GPVI lesions appeared to represent other conditions. Non-typical penoscopy findings, on the other hand, appeared to be histologically conspicuous for HPV-induced chan- ges in only 10 cases $(11 \%)$. This corresponds to a positive predictive value of $72 \%$, a negative predictive value of $23 \%$, a sensitivity of $85 \%$ and a specificity of $12 \%$ for the penoscopy assessment.

DNA hybridisation data are summarised in table 2. Overall positivity was $49 \%(32 / 65)$ with SB, $19 \%(14 / 72)$ with ISH and $72 \%$ (44/61) with PCR.

The correlation between the hybridisation analysis, penoscopy findings and histology results is given in table 3. HPV DNA positivity in typical/conspicuous penoscopy lesions was $49 \%(29 / 59)$ for SB, $14 \%(9 / 62)$ for ISH and $69 \%(36 / 52)$ for PCR. Correspondingly, in lesions that showed light microscopic signs of HPV infection HPV DNA was found in $62 \%$ (28/45) with SB, in $28 \%(14 / 50)$ with ISH and in $70 \%(33 / 47)$ with PCR. With either of the hybridisation assays HPV DNA was also detected in lesions considered as non-typical by penoscopy, as well as in biopsies without conspicuous light microscopic signs of viral influence. Thus, non-typical penoscopy lesions harboured HPV DNA in 50\% (3/6) with SB, in $50 \%(5 / 10)$ with ISH and in $89 \%(8 / 9)$ with PCR. In biopsy specimens that merely exhibited an eczematoid reaction the corresponding figures were $19 \%(3 / 16)$ and $75 \%$ (6/8) for SB and PCR respectively. One case being SB positive for an uncharacterised HPV type revealed a histological pattern characteristic for verruca plana. With PCR this sample was HPV 6 DNA positive. Another biopsy being PCR positive for HPV 6 and 16 was histopathologically typical for balanitis circinata parakeratotica. Three additional samples, apparently representing normal epithelium, contained HPV 6 in two of the cases, and HPV 16 in the third case, when tested with PCR.

All of the three PIN I lesions were HPV DNA positive in the PCR assay, one for HPV 6 and two for HPV 16; one of these lesions was also ISH positive for HPV 42. Of ten PIN II lesions, two were SB positive (one for HPV 6 and the other for HPV 16), one was ISH positive (HPV 6) and eight were $P C R$ positive (four for HPV 6, one for HPV 16 and three for both HPV 6 and 16). Of five PIN III lesions three were SB positive (two for HPV 16 and one for HVP 42); one of the two HPV 16 SB positive cases was also HPV 16 positive in ISH

Table 3 Correlation between HPV DNA hybridisation, penoscopy and histopathology findings (\%)

\begin{tabular}{|c|c|c|c|c|c|c|}
\hline \multirow[b]{3}{*}{ Penoscopy } & \multicolumn{6}{|c|}{ Hybridisation assay } \\
\hline & \multicolumn{2}{|c|}{ Southern blot $(n=65)$} & \multicolumn{2}{|c|}{ In situ $(n=72)$} & \multicolumn{2}{|c|}{$P C R(n=61)$} \\
\hline & Positive & Negative & Positive & Negative & Positive & Negative \\
\hline $\begin{array}{l}\text { Typical } \\
\text { Conspicuous } \\
\text { Non-typical }\end{array}$ & $\begin{array}{c}15 / 35(43) \\
14 / 24(58) \\
3 / 6(50)\end{array}$ & $\begin{array}{c}20 / 35(57) \\
10 / 24(42) \\
3 / 6(50)\end{array}$ & $\begin{array}{l}6 / 41(15) \\
3 / 21(14) \\
5 / 10(50)\end{array}$ & $\begin{array}{r}35 / 41(85) \\
18 / 21(86) \\
5 / 10(50)\end{array}$ & $\begin{array}{c}27 / 33(82) \\
9 / 19(47) \\
8 / 9(89)\end{array}$ & $\begin{array}{c}6 / 33(18) \\
10 / 19(53) \\
1 / 9(11)\end{array}$ \\
\hline Total & $32(49)$ & $33(51)$ & $14(19)$ & $58(81)$ & $44(72)$ & $17(28)$ \\
\hline $\begin{array}{l}\text { Histopathology } \\
\text { Typical } \\
\text { Conspicuous } \\
\text { Conspicuous + eczematoid } \\
\text { reaction }\end{array}$ & $\begin{array}{c}19 / 28(68) \\
6 / 12(50) \\
3 / 5(60)\end{array}$ & $\begin{array}{l}9 / 28(32) \\
6 / 12(50) \\
2 / 5(40)\end{array}$ & $\begin{array}{l}11 / 35(31) \\
3 / 10(30) \\
0 / 5(0)\end{array}$ & $\begin{array}{r}24 / 35(69) \\
7 / 10(70) \\
5 / 5(100)\end{array}$ & $\begin{array}{r}25 / 33(76) \\
6 / 12(50) \\
2 / 2(100)\end{array}$ & $\begin{array}{l}8 / 33(24) \\
6 / 12(50) \\
0 / 2(0)\end{array}$ \\
\hline $\begin{array}{l}\text { Eczematoid reaction only } \\
\text { Other conditions }\end{array}$ & $\begin{array}{l}3 / 16(19) \\
1 / 4(25)\end{array}$ & $\begin{array}{c}13 / 16(81) \\
3 / 4(75)\end{array}$ & $\begin{array}{l}0 / 15(0) \\
0 / 7(0)\end{array}$ & $\begin{array}{l}15 / 15(100) \\
7 / 7(100)\end{array}$ & $\begin{array}{l}6 / 8(75) \\
5 / 6(83)\end{array}$ & $\begin{array}{l}2 / 8(25) \\
1 / 6(17)\end{array}$ \\
\hline Total & $32(49)$ & $33(51)$ & $14(19)$ & $58(81)$ & $44(72)$ & $17(28)$ \\
\hline
\end{tabular}


Table 4 Correlation between penoscopy and histology findings versus HPV DNA detection in the various hybridisation assays

\begin{tabular}{|c|c|c|c|c|c|c|}
\hline \multirow[b]{3}{*}{$\begin{array}{l}\text { Hybridisation } \\
\text { assays performed }\end{array}$} & \multirow[b]{3}{*}{$\begin{array}{l}\text { Total samples } \\
\text { analysed }\end{array}$} & \multirow[b]{3}{*}{$\begin{array}{l}\text { Positive in either } \\
\text { test method }\end{array}$} & \multicolumn{4}{|c|}{ Classification of penoscopy and histology findings in HPV DNA positive biopsies } \\
\hline & & & \multicolumn{2}{|l|}{ Penoscopy } & \multicolumn{2}{|l|}{ Histology } \\
\hline & & & $\begin{array}{l}\text { Typicall } \\
\text { conspicuous }\end{array}$ & Non-typical & $\begin{array}{l}\text { Typicall } \\
\text { conspicuous }\end{array}$ & $\begin{array}{l}\text { Eczematoid reaction } \\
\text { and other conditions }\end{array}$ \\
\hline $\begin{array}{l}\text { SB + ISH + PCR } \\
\text { SB + ISH } \\
\text { SB + PCR } \\
\text { ISH + PCR } \\
\text { SB only } \\
\text { PCR only }\end{array}$ & $\begin{array}{r}27 \\
24 \\
8 \\
21 \\
6 \\
5\end{array}$ & $\begin{array}{r}26 \\
8 \\
6 \\
16 \\
6 \\
3\end{array}$ & $\begin{array}{r}25 \\
6 \\
5 \\
12 \\
6 \\
1\end{array}$ & $\begin{array}{l}1 \\
2 \\
1 \\
4 \\
2\end{array}$ & $\begin{array}{r}19 \\
5 \\
5 \\
13 \\
6 \\
3\end{array}$ & $\begin{array}{l}7 \\
3 \\
1 \\
3\end{array}$ \\
\hline Total & 91 & 65 & 55 & 10 & 51 & 14 \\
\hline
\end{tabular}

and another in PCR. A fourth PIN III lesion was PCR positive for HPV 6 only.

Table 4 summarises the correlation between the penoscopy and the histology findings versus the detection of any of the HPV types using the various hybridisation assays. Altogether $71 \%$ (65/91) of the biopsies were positive for HPV DNA in either assay. Of these, the penoscopy finding was classified as typical or conspicuous in 55 and as non-typical in another ten cases. The corresponding figures for HPV DNA negative cases were 23 and three, respectively. Thus, typical or conspicuous penoscopy patterns corresponded to a positive and negative predictive value of $71 \%$ and $23 \%$, respectively, as evaluated by all of the three hydridisation assays, corresponding to a sensitivity of $85 \%$ and a specificity of $12 \%$. If only SB and ISH results are considered, however, the negative and positive predictive values of penoscopy were both $45 \%$, the sensitivity $85 \%$ and the specificity $11 \%$.

Analogously, among the 65 HPV DNA positive biopsies 51 exhibited typical or conspicuous light microscopic signs of viral activity while 14 did not. The correspondig figures for HPV DNA negative cases were 15 and 11 , respectively. Accordingly, the positive and negative predictive values for the light microscopic criteria were $77 \%$ and $44 \%$ when all

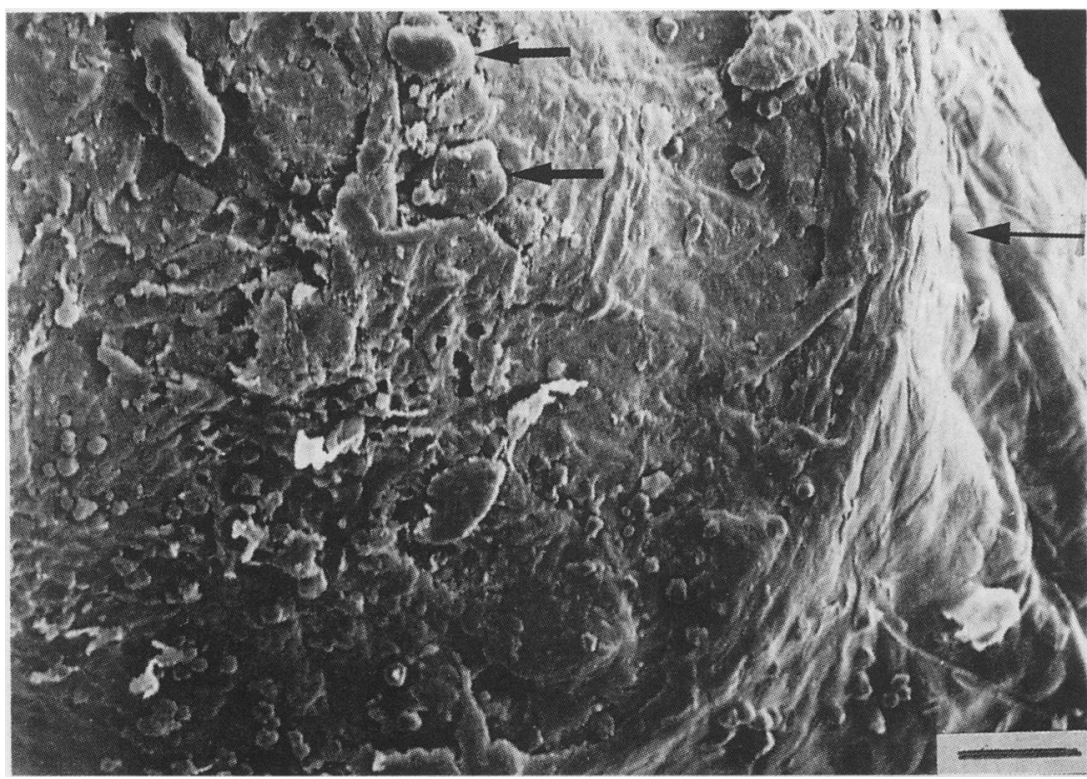

Figure 4 Part of a typical lesion with a marked, slightly elevated border between normal epidermis and the lesion (thin arrow). Within the lesion the surface is rugged with protrusions from beneath (thick arrows). Inset bar $=0.1 \mathrm{~mm}$. three virological assays are taken into account, corresponding to sensitivity and specificity values of $78 \%$ and $42 \%$ respectively. When limiting the analyses to $\mathrm{SB}$ and $\mathrm{ISH}$ results, the negative and positive predictive values of light microscopy were $59 \%$ and $80 \%$, respectively, corresponding to a sensitivity of $88 \%$ and a specificity of $44 \%$

\section{Group B}

In the scanning electron microscope the surface of the normal stratum corneum appeared smooth with regular furrows. The analysis of the surface structure of the excised lesions displayed a spectrum of changes. A common feature (fig 4) was the appearance of a distinct, somewhat elevated border between the lesion and the normal stratum corneum with a depressed surface centrally in the lesion. Within the lesion the surface of stratum corneum was smooth in some, while others exhibited a disturbed, "rugged" appearance in which the smooth surface was replaced with a protrusion from beneath (figs 5 and 6 ).

\section{Discussion}

In the present material the tissue collected for light microscopic evaluation was not identical to that analysed for HPV DNA but rather represented adjacent acetowhite epithelium. Furthermore, only one biopsy was collected from each individual, who was usually afflicted with multiple lesions. Because histological features of HPV infection often are focal, ${ }^{42}$ the possibility of sampling error evidently exists. Yet, some relevant results emanate from the present study.

The presence of koilocytosis, reflecting a cytopathic effect of reproductive HPV infection, represents the only pathognomonic light microscopic sign of biological activity. ${ }^{172733}$ This marker correlates best with classical condylomas and is less consistently present in subclinical GPVI..$^{35}$ Yet, the presence of koilocytosis in $48 \%$ of our biopsies agrees well with a number of previous reports on subclinical lesions. 1530334445 Another 25\% of the specimen exhibited less specific structural changes that were highly indicative for active HPV infection. These findings are congruent with the fact that $86 \%$ of the lesions were characterised penoscopically as typical or conspicuous for GPVI. Nevertheless, our study clearly demonstrates that differential diagnostic considerations are of major importance when 


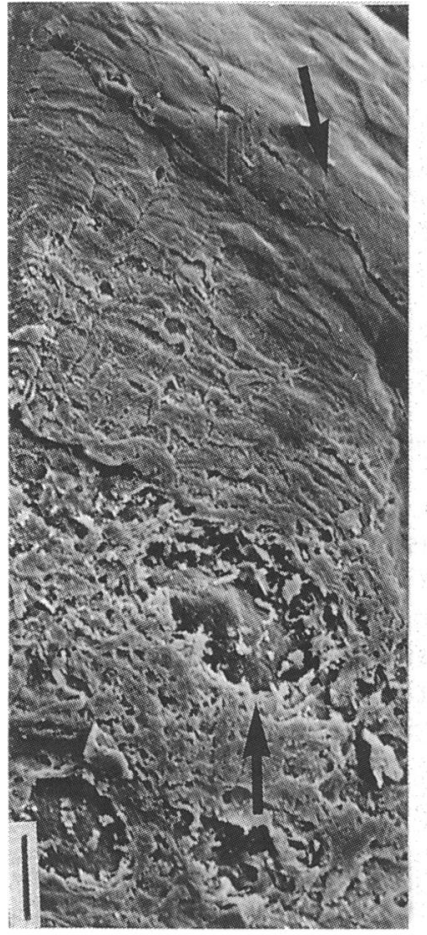

(a)

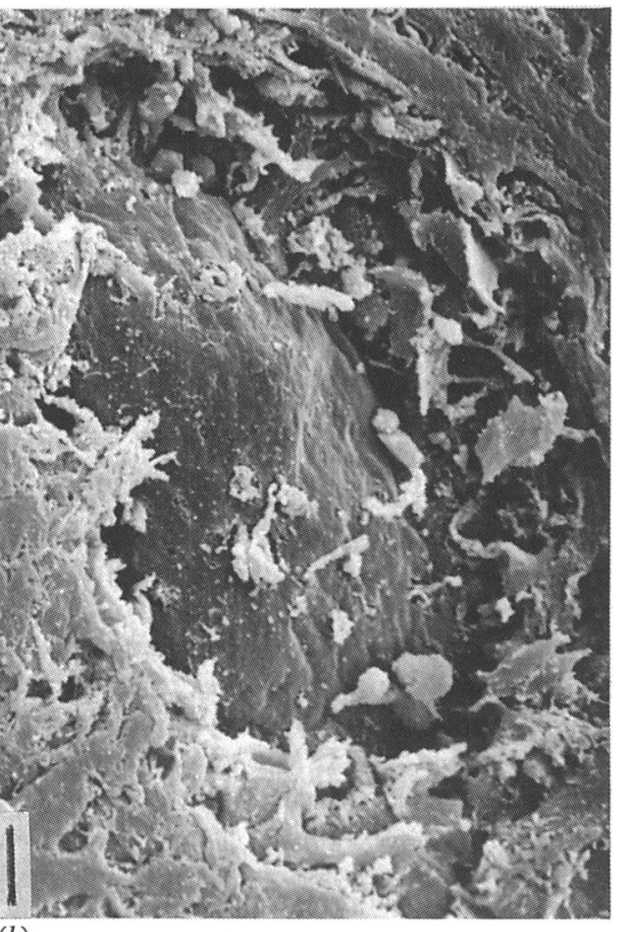

Figure 5 (a) shows part of a lesion with the marked border (upper arrow) and rugged surface with protrusions (lower arrow). Inset bar $=0.05 \mathrm{~mm}$. (b) shows the protrusion in figure $5 a$ at a higher magnification. Inset bar $=0.01 \mathrm{~mm}$.

acetowhite genital lesions are detected.

Inflammatory conditions such as balanoposthitis as the cause of acetowhitening has been considered also previously. ${ }^{19} 46$ In $7 \%$ of our cases inflammatory cell infiltrates coexisted with conspicuous HPV changes. The existence of merely an eczematoid reaction was found in $19 \%$ of the biopsy specimens; in these cases HPV DNA was detected in $19 \%$ by SB and in $75 \%$ by PCR. These observations indicate that the concurrent presence of GPVI and local inflammation is not uncommon. This concept also agrees with the high frequency $(50-89 \%)$ of HPV DNA positivity that was detected in lesions penoscopically classified as non-typical; in many of these cases the acetowhitening occurred on an erythematous epithelium. An

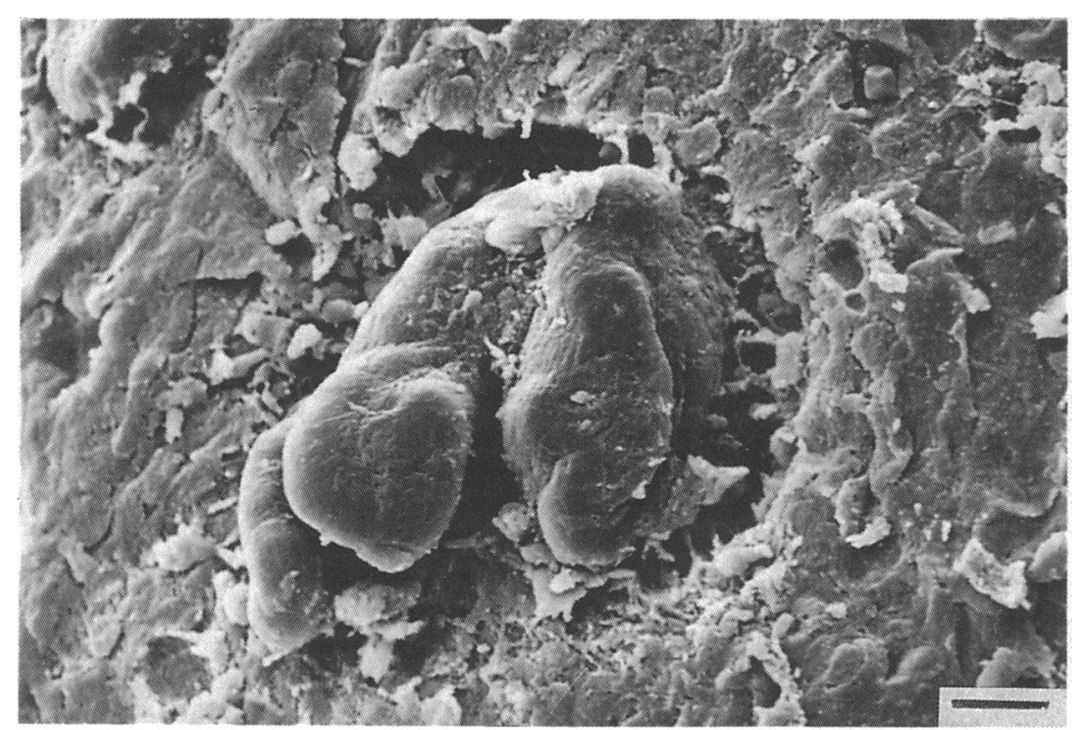

Figure 6 Part of a typical lesion with a nodular protrusion from beneath through the surface of the lesion. Inset bar $=0.015 \mathrm{~mm}$. association between HPV influence and inflammation has also been substantiated by Arumainagyam et $a l,{ }^{47}$ who found that koilocytotic changes were present in 49 of 50 biopsy specimens taken from men presenting with a patchy balanoposthitis.

As is apparent by penoscopy (fig 1 ) as well as scanning electron microscopy (fig 4) some acetowhite lesions exhibit a central groove in which the epidermis apparently is quite thin. It seems reasonable to believe that associated epithelial fissures represent loci minores for the entrance of exogenous toxic and/or infectious stimuli that may initiate an inflammatory response. These epithelial breaks may possibly also facilitate the transmission of blood-borne agents such as syphilis, HBV (hepatitis B virus) and HIV (human immunodeficiency virus). This concept harmonises well with the scanning electron microscopic findings, indicating that capillaries protrude through the epidermis in some of the lesions. Symptoms such as itching, burning or dyspareunia have been associated with GPVI on the female genitals and have been denominated as "papillomavirus vulvovaginitis" and "pruritic vulvar squamous papillomatosis". ${ }^{448-51}$ We propose the term "papillomavirus balanoposthitis" for corresponding illness in males, and we suggest that recurrent balanoposthitis and vulvovaginitis of otherwise unknown aetiology should be investigated for the potential of an underlying GPVI.

In a subsequent pilot study on 26 uncircumcised males presenting themselves with various penile symptoms such as itching, burning and/or dyspareunia, and in whom acetowhite lesions were detected in the preputial cavity, we found that topical antiinflammatory therapy for two weeks resulted in a complete or partial clearing of the acetowhitening in two thirds of the patients (von Krogh \& Wikström, unpublished). Lesions that most consistently responded to antiinflammatory therapy in general exhibited a ragged, irregular border and a varying degree of adjacent erythema. However, in a number of cases such lesions concurred with sharply demarcated lesions that we considered as conspicuous for GPVI. Further evaluation of these findings is required, however, to ascertain the potential coexistence of penile HPV lesions with balanoposthitis.

An inflammatory response in close vicinity to HPV induced epithelial changes may also represent a secondary immunological response. It is well appreciated that spontaneous wart rejection is associated with a dermal accumulation of lymphocytes and macrophages that subsequently penetrate into the epidermis, causing an eczematoid reaction similar to that observed in a quarter of our patients. ${ }^{52-54} \mathrm{~A}$ phenotypic characterisation of the inflammatory cells deserves further attention in future studies on such patients. Also, the natural course of subclinical GPVI in men should be investigated; a marked focal inflammatory response might very well be associated with a favourable outcome. Interestingly, of lesions that histologically showed the mere 
existence of inflammation, HPV DNA was detected in no sample analysed with ISH but in $19 \%(3 / 16)$ of specimens investigated with SB and as much as $75 \%(6 / 8)$ of those examined with PCR. Owing to the differences in sensitivity for these assays, these findings may very well reflect that a relatively low HPV DNA copy number exists in lesions being in the phase of involution.

Several screening investigations have demonstrated that subclinical GPVI is quite common in sexually active individuals but that the type specific HPV carriage rate differs from that of condylomata patients. ${ }^{55}$ Using dot-blot hybridisation on exfoliated cervical cells, Soares et al, ${ }^{56}$ detected HPV $6 / 11$ in $4-7 \%$ as compared with positivity rates of $17-29 \%$ for HPV $16 / 18$, of $18-24 \%$ for HPV $31 / 33 / 35$ and of $51 \%$ for other uncharacterised HPV types. Using the more sensitive SB assay on cervical smears Rosenfeld et $a l^{57}$ detected HPV 6/11 in $6 \%$ of the positive samples as compared with HPV 16 in $16 \%$, HPV 18 in $15 \%$ and an uncharacterised HPV type in another $67 \%$ of cases. These results are congruent with previous reports on biopsy specimens sampled from penoscopically identified lesions of males. Thus, Barrasso et al ${ }^{13}$ found that condylomas in general were associated with HPV 6,11 or 42, while subclinical lesions predominantly were associated with the HPV types 16,18 or 33. In our material, however, the type specific HPV distribution was somewhat different with a relatively high frequency of HPV 6/11 that amounted to $31 \%$ with SB, to $14 \%$ with ISH and to $59 \%$ with PCR (table 2). We did not detect the presence of HPV 18 in any case, a finding corresponding to previous investigations on penile warts in our geographical area indicating that HPV 18 infections are rare ${ }^{58} \mathrm{As}$ accounted for in previous studies concurrent infection with more than one HPV type was not uncommon. ${ }^{585}$

The presence of a penile lesion being histopathologically characteristic of verruca plana has not been reported previously. The HPV DNA detected in SB did not hybridise with any of the probes used by us but possibly correspond to a genome related to HPV types 3, 10 or $28 .{ }^{60}$

As demonstrated by Barrasso et al ${ }^{13}$ acetowhite subclinical penile lesions may reveal the presence of "bowenoid" epithelial changes (PIN III), indicating infection with oncogenic HPV types, in particular HPV 16. PIN III was found in five of our specimens. As merely a single biopsy specimen was collected for light microscopy in our material, the potential of sampling errors entails that the prevalence of PIN might be considerably higher in sexually active males than found in the present study. We detected HPV 16 DNA in two of the PIN III lesions with either of the hybridisation assays, while one additional sample harboured HPV 42 as revealed by SB. While originally isolated from a case of $\mathrm{CIN}^{61} \mathrm{HPV} 42$ has subsequently been associated with benign penile lesions ${ }^{13}$ and has not been considered an oncogenic HPV type. ${ }^{62}$ However, our results indicating that HPV 42 may possess an oncogenic potential, deserve further attention.

For subclinical GPVI no single diagnostic "gold standard" exists. Acetowhite mucosal changes comprise a spectrum of colposcopic and histological abnormalities. Accordingly, the clinician and the pathologist will often encounter lesions that do not unequivocally fulfill all of the criteria for GPVI. The use of ISH for HPV DNA detection has proved valuable for increasing the accuracy of light microscopic evaluation and has been recommended as a quality control procedure for the histological diagnosis of HPV-related lesions. ${ }^{63}$ Still, we feel that a combined appraisal of clinical presentation, use of the acetic acid test combined with colposcopic evaluation of lesional topography, and application of conventional histology criteria will be satisfactory in the predominant number of routine cases. The potential value of using virological methods in clinical routine has been the cause of much controversy recently, ${ }^{64} 65$ in particular with regard to the PCR methodology that possibly may be able to pick up latent infections as well. ${ }^{36} \mathrm{HPV}$ was detected by the highly sensitive PCR assay in as much as $69 \%$ of typical/conspicuous penoscopy lesions and $70 \%$ of biopsies being light microscopic typical/conspicuous of viral influence but also in $60 \%$ of samples that were histologically normal. Accordingly, the relevance of applying the PCR method in the analysis of our study is unclear. Nonetheless, the addition of virological methods to conventional histopathology did not improve the diagnostic accuracy of our penoscopy findings. Thus, the positive predictive value between penoscopy and light microscopy $(72 \%)$ is higher than the corresponding value for virological methods whether calculated on the basis of SB and ISH results alone $(45 \%)$, or applying PCR results as well $(71 \%)$.

The startling flow of epidemiological data presented during the past few years, revealing that latent or subclinical GPVI is more than 100 times as common as manifest wart disease, ${ }^{55}$ has created some ambiguity among clinicians on the optimal management of patients with GPVI. It has been suggested that women with CIN may benefit from examination and treatment of subclinical lesions of their male partners, aiming at optimising the cure rates of CIN. However, it has been shown that the treatment failure rate of women with CIN, whose partners are carefully treated, does not differ from that of women whose partners remain untreated. ${ }^{66}$ Accordingly, routine screening with the acetic acid test in males whose partners have CIN does not rely on a somatic rationale. In the light of available epidemiological data it rather seems warranted to discourage a use of the acetic acid test for screening purposes, as an ill considered use of the test may create unnecessary fear and anguish in presumably healthy individuals. It rather seems rational to await a spontaneous resolution of asymptomatic subclinical GPVI of the outer genitals. Although current knowledge on the natural course of such lesions is quite limited, studies on cervical lesions 
indicate that the majority of cases will clear spontaneously within a period of 5-6 years. 5667 Age related prevalence studies on HPV carriage are in agreement with this concept. ${ }^{5658}$ It has also been demonstrated that bowenoid lesions of the outer genitals appear to regress spontaneously in up to $75 \%$ when observed for a period of 1-2 years. ${ }^{52}$

Patient management must rather rely upon pragmatic approaches of diagnosing and treating clinically relevant disease. This approach entails eradication of condylomas and overt bowenoid papulosis, of moderate to servere CIN, as well as of acetowhite lesions if these are associated with any symptoms. For this purpose it is important that physicians are familiar with the colposcopic criteria that indicate underlying GPVI and also are aware that false positivity from the acetic acid test may arise from other conditions such as lichen sclerosus et atrophicus and, above all, of inflammatory conditions.

1 Jenison SA, Yu X, Valentine JM, et al. Evidence of prevalent genital-type human papillomavirus infections in adults and children. J Infect Dis 1990;162:60-69.

2 Butler S, Molinari JA, Plezia RA, Chandrasekar P, Venkat $H$. Condyloma acuminatum in the oral cavity: four cases and a review. Rev Infect Dis 1988;10:544-50.

3 Chang F, Syrjänen S, Shen Q, Ji H, Syrjänen K. Human Papillomavirus (HPV) DNA in esophageal precancer lesions and squamous cell carcinomas from China. Int $J$ Cancer 1990;45:21-5.

4 Kataja V, Syrjänen K, Mäntyjärvi R, et al. Prospective follow-up of cervical HPV infections life table analysis of histopathological, cytological and colposcopic data. Eur J Epidemiol 1989;5:1-7.

5 Syrjänen KJ. Epidemiology of human papillomavirus (HPV) infections and their association with genital (HPV) infections and their association with
squamous cell cancer. APMIS 1989;97:957-70.

6 Syrjänen KJ. Natural history of genital human papillomavirus infections. Papillomavirus Rep 1990;1:1-5.

7 Durst M, Gissmann L, Ikenberg H, zur Hausen H. A papillomavirus DNA from a cervical carcinoma and its prevalence in cancer biopsy samples from different geographic regions. Proc Natl Sci USA 1983;80:3812-5.

8 Crum CP, Mitao M, Levine RU, Silverstein S. Cervical papillomaviruses segregate within morphologically distinct precancerous lesions. $J$ Virol 1985;ii:675-81.

9 Gupta J, Pilotti S, Rilke F, Shah K. Association of human papillomavirus type 16 with neoplastic lesions of the vulva and other genital sites by in situ hybridization. $\mathrm{Am}$ Pathol 1987;127:206-15.

10 Gissmann L, Boshart M, Durst M, Ikenberg H, Wagner D, zur Hausen $H$. Presence of human papillomavirus in genital tumors. J Invest Dermatol 1984;83:26-28.

11 Boshart M, Gissmann L, Ikenberg H, Kleinheinz A, Scheurlen W, zur Hausen H. A new type of papillomavirus DNA, its presence in genital cancer biopsies and in cell lin

12 Gissmann L, Wolnik L, Ikenberg H, Koldovsky U, Schnurch HG, zur Hausen $H$. Human papillomavirus types 6 and 11 DNA sequences in genital and laryngeal papillomas and in some cervical cancers. Proc Natl Acad Sci USA 1983;80:560-3.

13 Barrasso R, De Brux J, Croissant O, Orth G. High prevalence of papillomavirus-associated penile intraepithelial neoplasia in sexual partners of women with cervical intraepithelial neoplasia. N Engl J Med 1987;317:916-23.

14 Bodén E, Eriksson A, Rylander E, von Schultz B. Clinical characteristics of papillomavirus vulvovaginitis. A new entity with oncogenic potential. Acta Obstet Gynecol Scand 1988;67:147-51.

15 Bodén E, Rylander E, Evander M, Wadell G, von Schoult B. Papillomavirus infection of the vulva. Acta Obstet Gynecol Scand 1989;68:179-84.

16 von Krogh G, Rylander E. Clinical evaluation. In: von Krogh G, Rylander E, eds: GPVI. A survey For the Krogh G, Rylander E, eds: GPVI. A survey For the
Clinician. Karlstad, Sweden. Conpharm AB/KABI PharClinician. Karlstad, Sweden. Conpharm

17 Krebs HB, Schneider V. Human papillomavirus-associated lesions of the penis: colposcopy, cytology and histology. Obstet Gynecol 1987;70:299-304

18 Schneider A, Kirchmayr R, de Villiers E-M, Gissmann L. Subclinical human papillomavirus infections in male sexual partners of female carriers. J Urol 1988;140: $1431-4$.

19 Schultz RE, Skelton HG. Value of acetic acid screening for flat genital condylomata in men. $J$ Urol 1988;139:777-9.

20 Reid R, Greenberg M, Jenson AB, et al. Sexually transmitted papillomaviral
21 Bergeron C, Ferenczy A, Shah KV, Naghashfar Z. Multicentric Human Papillomavirus infections of the female centric Human Papillomavirus infections of the female genital tract: Correlation of viral typers with abnormal mitotic figures, colposcopic pres

22 Byrne MA, Taylor-Robinson D, Anderson MAC, Mason P Harris JRW. Value of colposcopy in sexually transmitted diseases clinic based on first year's experience. Genitourin Med 1989;65:42-5.

23 Byrne MA, Walker MM, Leonard J, Pryce D, TaylorRobinson D. Recognising overt disease in women with chronic vulval symptoms attending an STD clinic: value of detailed examination including colposcopy. Genitourin Med 1989;65:46-9.

24 Rylander E, Eriksson A, Ingelman-Sundberg $\mathrm{H}$, von Schoultz B. Classification of colposcopic findings associated with human papillomavirus infection of cervix uteri and vagina. Cervix 1985;3:123-32.

25 Sand PK, Bowen LW, Blischke SO, Ostergard DR. Evaluation of male consorts of women with human papilloma virus infection. Obstet Gynecol 1986;68:679-81.

26 Rosemberg SK. Subclinical Papilloma Viral Infection of male genitalia. Urology 1985;26:554-7.

27 Koss LG. Cytologic and histologic manifestations of human papillomavirus infection of the female genital tract and their clinical significance. Cancer 1987;60:1942-50.

28 Koss LG. Cytologic and histologic manifestations of human papillomavirus infection of the uterine cervix. Cancer Detect Prev 1990;14:461-4.

29 Syriänen KJ. Histopathology, cytology, immunohistochemistry and HPV typing techniques. In: von Krogh G, Rylander E, eds: GPVI. Genitoanal Papillomavirus Infection. A survey for the Clinician. Karlstad, Sweden Conpharm

30 Spitzer M, Chernys AE, Hirschfield L, et al. Assessment of criteria used in the histologic diagnosis of Human Papillomavirus-related disease of the female lower genital tract. Gynecol Oncology 1990;38:105-109.

31 Nuovo GJ. Human papillomavirus DNA in genital tract lesions histologically negative for condylomata. Analysis by in situ, Southern blot hybridization and the polymerase chain reaction. Am J Surg Pathol 1990;14:643-51.

32 Wendler $D$. The frequency of Human Papilloma Virus type 31,33 and 35 in cervical intraepithelial neoplasia. Geburtsh u Frauenheilk 1990;50:110-2.

33 Sehgal VN, Koranne RV, Srivastava SB, Gupta MM, Luthra UK. Clinicopathology and immunohistochemistry of genital warts. Int J Dermatol 1988;27:690-4.

34 Nuovo GJ. A comparison of slot blot, Southern blot and in situ hybridisation analyses for human papillomavirus 673-8.

35 Nuovo GJ, Hochman HA, Eliezri YD, Lastarria D, Comite SL, Silvers DN. Detection of human papillomavirus DNA in penile lesions histologically negative for condylomata. Analysis by in situ hybridization and the lomata. Analysis by in situ hybridization and the polymerase chain

36 Guerrero E, Shah KV. Polymerase chain reaction in HPV diagnosis. Papillomavirus Report 1991;2:115-18.

37 Syrjänen SM, von Krogh G, Syrjänen KJ. Detection of human papillomavirus DNA in anogenital condylomata in men using in situ DNA hybridisation applied to paraffi sections. Genitourin Med 1987;63:32-9.

38 Syrjänen KJ. Human papillomavirus (HPV) infections of the female genital tract and their associations with intraepithelial neoplasia and squamous cell carcinoma. Pathol Ann 1986;21:53-89.

39 Syrjänen S, Partanen P, Mäntyjärvi R, Syrjänen K. Sensitivity of in situ hybridisation techniques using biotinand 35 S-labelled human papillomavirus (HPV) DNA probes. J Virol Method 1988;19:225-38.

40 Saiki RK, Gelfand DM, Stoffel S, et al. Primer-directed enzymatic amplification of DNA with a thermostable enzymatic amplification of DNA with a
DNA polymerase. Science 1988;239:487-91.

41 Wikström A, Lidbrink P, Johansson B, von Krogh G. Penile human papillomavirus carriage among men attending Swedish STD clinics. Int J STD and AID S 1991;2:105-9.

42 Crum CP, Nuovo $G$, Friedman D, Silverstein SJ. Accumulation of RNA homologous to human papillomavirus type 16 open reading frames in genita precancers. $J$ Virol 1988;62:84-90.

43 Schultz RE, Miller JW, MacDonald GR, et al. Clinical and . J Urol 1990;143:920-3.

44 Mittal KR, Chan W, Demopoulos RI. Sensitivity and specificity of various morphological features of cervical specifity of various morphological features of cervical
condylomas. Arch Pathol Lab Med 1990;114:1038-41.

45 Nuovo GJ, Friedman D, Richart RM. In Situ Hybridization analysis of Human Papillomavirus DNA segregation patterns in lesions of the female genital tract. Gynecol Oncol 1990;36:256-62.

46 Griffiths M, Penna LK, Tovey SJ. Aceto-white change of the glans penis associated with balanitis not human papillomavirus infection. Int $J \quad S T D$ and $A I D S$ 1991;2:211-12.

47 Arumainayagam JT, Sumathipala AHT, Smallman LA Shahmanesh $M$. Flat condyloma of the penis presenting a patchy balanoposthitis. Genitourin Med 1990;66:251-3.

48 Growdon WA, Fu YS, Lebherz TB, Rapkin A, Mason GD Parks G. Pruritic vulvar squamous papillomatosis: evidence for human papillomavirus and its etiology. Obste Gynecol 1985;66:564-8.

49 Turner MLC, Marinoff SC. Association of human papillomavirus with vulvodynia and the vulvar vestibulitis

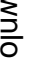


syndrome. J Reprod Med 1988;28:533-7.

50 Deitch KV, Smith JE. Symptoms of chronic vaginal infection and microscopic condyloma in women. $J$ Obstet Gynecol Neonatal Nurs 1990;19:133-8.

51 Bodén E. Human Papilloma Virus. Association with Vulvovaginitis and Genital Intra-epithelial Neoplasia. Thesis. Umea University Medical Dissertations 1991;ii:1-54.

52 Jablonska S, Majewski S, Malejczyk J. HPV infection and immunological responses. In: von Krogh G, Rylander E, immunological responses. In: von Krogh G, Rylander E, eds. GPVI. Genitoanal Papillomavirus Infection. A survey for the clinician. Karlstad, Sweden. Co

53 McMillan A, Bishop PE, Fletcher S. An immunohistological study of condylomata acuminata. Histopathol 1990;17: 45-52.

54 Bishop PE, McMillan A, Fletcher S. An immunohistological study of spontaneous regression of condylomata acuminata. Genitourin Med 1990;66:79-81.

55 von Krogh G. Genitoanal papillomavirus infection: diagnostic and therapeutic objective in the light of current epidemiological observations. Int $J$ STD and AIDS 1991;2:391-404.

56 Soares VRX, Nieminen $P$, Aho $M$, Vesterinen E, Oakeri A, Paavonen J. Human papillomavirus DNA in unselected Paavonen J. Humgn papillomavirus DNA in unselected pregnant and

57 Rosenfeld WD, Vermund SH, Wentz SJ, Burk RD. High prevalence rate of human papillomavirus infection and association with abnormal Papanicolaou smears in sexually active adolescents. $A m J D$ is Child 1989;143:1443-7.

58 von Krogh G, Syrjänen SM, Syrjänen KJ. Advantage of human papillomavirus typing in the clinical evaluation of genitoanal warts. J Amer Acad Dermatol 1988;18:495-503.
59 Nuovo GJ, Darfler MM, Impraim CC, Bromley SE Occurrence of multiple types of human papillomavirus in genital tract lesions. Am J Pathol 1991;138:53-8.

60 de Villiers E-M. Human Papillomaviruses. Reference chart. Roche Biomedical Laboratories Inc, Burlington, North Carolina \& Roche Diagnostic Systems, Inc, Montclair, New Jersey.

61 Beaudenon S, Kremsdorf D, Obalek S, Jablonska S, et al. Plurality of genital human papillomaviruses: characterization of two new types with distinct biological properties. tion of two new types with
Virology $1987 ; 161: 374-84$.

62 zur Hausen $H$. The role of papillomavirus in anogenital cancer. Scand J Infect Dis Suppl1990;69:107-11.

63 Richart RM, Nuovo GJ. Human papillomavirus in situ hybridizaton may be used for the quality control of genita tract biopsies. Obstet Gynecol 1990;75:223-6.

64 Reid R, Lorincz AT. Should family physicians test for human papillomavirus infection? An opposing view. $J$ Fam Pract 1991;32:183-8.

65 Nuovo GJ, Nuovo J. Should family physicians test for human papillomavirus infection? An opposite view. J Fam Pract 1991;32:188-92.

66 Krebs H-B, Helmkamp BF. Does the treatment of genital condylomata in men decrease the treatment failure rate of cervical dysplasia in the female sexual partner? Obstet Gynecol 1990;76:660-3.

67 Syriänen K, Syriänen S. Epidemiology of human papillomavirus infections and genital neoplasia. Scand J papillomavirus infections and
Infect Dis Suppl 1990;69:7-17.

68 Köchel HG, Teichman A, Eckardt N, Arendt P, Kuhn W, Thomssen $R$. Occurrence of human papillomavirus DNA types 16 and 18 (HPV 16/18) in cervical smears as compared to cytological findings. Int J Gynecol Obste 1990;31:145-52. 